\title{
Hen Egg as an Antioxidant Food Commodity: A Review
}

\author{
Chamila Nimalaratne and Jianping $\mathrm{Wu}$ * \\ Received: 22 July 2015 ; Accepted: 18 September 2015 ; Published: 24 September 2015 \\ Department of Agricultural, Food and Nutritional Science (AFNS), 4-10 Agriculture/Forestry Centre, \\ University of Alberta, Edmonton, AB T6G 2P5, Canada; nimalara@ualberta.ca \\ * Correspondence: jwu3@ualberta.ca; Tel.: +780-492-6885; Fax: +780-492-4265
}

\begin{abstract}
Intake of antioxidants through diet is known to be important in reducing oxidative damage in cells and improving human health. Although eggs are known for their exceptional, nutritional quality, they are not generally considered as antioxidant foods. This review aims to establish the importance of eggs as an antioxidant food by summarizing the current knowledge on egg-derived antioxidants. Eggs have various natural occurring compounds including the proteins ovalbumin, ovotransferrin and lysozyme in egg white, as well as phosvitin, carotenoids and free aromatic amino acids in egg yolk. Some lipophilic antioxidants such as vitamin E, carotenoids, selenium, iodine and others can be transferred from feed into egg yolk to produce antioxidant-enriched eggs. The bioactivity of egg antioxidants can be affected by food processing, storage and gastrointestinal digestion. Generally thermal processing methods can promote loss of antioxidant properties in eggs due to oxidation and degradation, whereas gastrointestinal digestion enhances the antioxidant properties, due to the formation of new antioxidants (free amino acids and peptides). In summary, in addition to its well-known nutritional contribution to our diet, this review emphasizes the role of eggs as an important antioxidant food.
\end{abstract}

Keywords: hen eggs; naturally-occurring antioxidants; antioxidant-enriched eggs; processing; gastrointestinal digestion

\section{Antioxidants in Human}

An antioxidant can be defined as "any substance that delays, prevents or removes oxidative damage to a target molecule" [1] or "any substance that directly scavenges reactive oxygen species (ROS) or indirectly acts to up-regulate antioxidant defenses or inhibit ROS production" [2]. The human body produces many enzymatic and nonenzymatic endogenous antioxidants in order to provide the primary defense against superoxide and hydrogen peroxides. The major antioxidant enzymes are superoxide dismutase (SOD), catalase (CAT), glutathione peroxidase (GPx), glutathione reductase (GRx) and peroxiredoxins [3]. Nonenzymatic endogenous antioxidants include coenzyme Q10, vitamin A, glutathione, uric acid, lipoic acid, bilirubin, L-carnitine, etc. [3,4]. There are many different mechanisms by which antioxidants exert protective effects against oxidative damage. They can scavenge free radicals and other reactive species by stopping initiation or propagation of free radicals chain reactions in the system, scavenging singlet oxygen, sequestering transition metal ions to prevent generation of free radicals, reducing localized oxygen concentration, and inhibiting pro-oxidative enzymes such as lipoxygenases $[3,5,6]$. Antioxidants can work synergistically with each other against different types of free radicals and reactive species. The most efficient enzymatic antioxidants are glutathione peroxidase (GSH-Px), catalase, and SOD [7]. GSH-Px and SOD (in two forms: CuZnSOD and MnSOD) are found in mitochondria and cytosol, whereas catalases are located in peroxisomes [8]. SOD converts superoxide into $\mathrm{H}_{2} \mathrm{O}_{2}$ and oxygen, while GSH-Px and catalase 
react with $\mathrm{H}_{2} \mathrm{O}_{2}$ to produce water and oxygen [8]. Although the gene expression and activity of these enzymes in the cell are well regulated to maintain redox homeostasis, internal and external factors such as aging, inflammation, smoking and toxins can influence the balance [7].

Glutathione (GSH) is a water soluble tripeptide (L- $\gamma$-glutamyl-L-cysteinylglycine) that can react with ROS using its thiol group and oxidized to form glutathione disulfide (GSSG) which can then convert back to GSH by combined action of NADPH (reduced nicotinamide-adenine di-nucleotide phosphate) cofactor and GRx [3,4]. GSH is also involved in regeneration of ascorbate [3]. Coenzyme Q10, present in all cells and membranes, is the only endogenously synthesized liposoluble antioxidant. It is an effective antioxidant which prevents lipid peroxidation during the initiation step and is involved in regenerating vitamin E [9]. Uric acid is a metabolic product of purine nucleotide, and can be absorbed back into the body during kidney filtration into the plasma [3]. A potent singlet oxygen and hydroxyl radical scavenger, uric acid prevents lysis of red blood cells by peroxidation [10].

\section{Dietary Antioxidants}

Intake of antioxidants through diet is thought to be important in reducing oxidative damage [11-14]. These antioxidants play a critical role in protecting cellular components from potentially damaging ROS and thereby maintaining homeostasis and optimal cellular functions. Synthetic antioxidants such as butylated hydroxyanisole (BHA), butylated hydroxytoluene (BHT), tert-butylhydroquinone (TBHQ) and propyl gallate (PG) have been used in both food and pharmacological applications [15]. However, because of the possible toxic and carcinogenic effects associated with BHT and BHA, their use is legally restricted $[16,17]$. As a result, there is a growing interest in using natural antioxidants for food and therapeutic applications which prompt the scientific community to explore new sources of natural and dietary antioxidants $[3,15,18,19]$. The most known groups of natural antioxidants are vitamin $C$, vitamin E, carotenoids and flavonoids and more recently, peptides with antioxidant properties derived from various plant and animal sources $[15,19]$.

Most of the plant derived antioxidant compounds are phytochemicals including phenolics, flavonoids and carotenoids whereas the prominent animal-derived antioxidants are amino-derived compounds such as amino acids, peptides and proteins [20].

Vitamin E, a well-known chain breaking antioxidant, prevents propagation of lipid peroxidation reactions by donating its phenolic hydrogen to the lipid peroxyl radical [15]. Vitamin E will become a radical itself (tocopheroxyl radical), but is more stable due to delocalization of the solitary electron over the aromatic ring structure $[15,21]$. Lipid soluble vitamin $\mathrm{E}$ is considered the most important antioxidant in preventing lipid peroxidation. Carotenoids are another class of lipid soluble compounds with antioxidant properties. The main mechanisms are singlet oxygen quenching, reacting with free radicals and delocalizing the unpaired electrons with the aid of unsaturation and resonant stabilization [22,23]. Singlet oxygen scavenging ability of lutein and zeaxanthin is suggested as the main protective mechanism of eye macular against blue light-induced oxidative damage [24,25]. Carotenoids can also prevent lipid peroxidation and play a protective role in carcinogenesis [26]. Although beneficial at moderate concentration, high doses of supplementation of $\beta$-carotenoids in high concentration can act as a pro-oxidant [22,27].

Vitamin $\mathrm{C}$ or ascorbic acid, a water soluble vitamin, has been shown to be effective against the superoxide radical anion, $\mathrm{H}_{2} \mathrm{O}_{2}$, the hydroxyl radical and singlet oxygen $[15,28]$. It also acts synergistically with vitamin $\mathrm{E}$ by reacting with tocopheroxyl radical to regenerate its antioxidant ability [29]. Flavonoids represent a class of phytochemicals which are known to have antioxidant properties depending on structural features such as the number and position of the hydroxyl groups and number of phenolic rings, etc. [27,30]. They have been reported to scavenge peroxyl radicals, inhibit lipid peroxidation, and chelate metal ions [27,31].

Fruits, vegetables, oil seeds, nuts, cereals, spices, herbs, and grains are important sources of antioxidants such as phenolics, flavonoids and carotenoids. A great deal of research has been conducted on their antioxidant properties in vivo, in vitro as well as on extraction and purification 
methods, applications in food products, bioavailability, and anti-nutritional aspects [32-36]. Among many plant sources, berries and fruits are known for their high phenolic content including phenolic acids, and anthocyanins and their high antioxidant capacity [37]. Most vegetables including tomatoes, red pepper, Brassica vegetables, onion, garlic and red beet are found to have high antioxidant capacity mainly attributed to their flavonoid, carotenoid, vitamin C contents [38-41]. Although cereal grains are not considered rich sources of antioxidants compared to fruits and vegetables, grains and grain products are staple food components in the human diet and therefore their contribution is still significant [42-44]. The major phenolic compounds are phenolic acids such as ferulic acid, the dominating phenolic acid in wheat, caffeic acid, $p$-coumaric acid, $p$-hydroxybenzoic acid, vanillic acid and protocatechuic acid, etc. [44]. In addition, they contain other compounds which may exert antioxidant effects, for example, vitamin E, folates, minerals (iron, zinc) and trace elements (selenium, copper and manganese), carotenoids, etc. It has been suggested that antioxidant capacity of cereals is usually underestimated because of the bound phenolic compounds which do not contribute during in vitro assays, but can be released in the gut to exert the antioxidant activity $[45,46]$.

Compared to antioxidants from plant sources, the available research on animal-derived antioxidants is limited. Proteins and peptides have been known to inhibit lipid oxidation through inactivation of ROS, scavenging free radicals, chelation of prooxidative transition metals, reduction of hydroperoxides, and alteration of the physical properties of food systems [47]. The most abundant antioxidant dipeptides in skeletal muscles are histidine-containing dipeptides, such as carnosine and anserine [48]. The peptide concentration varies from about $500 \mathrm{mg}$ per $\mathrm{kg}$ of chicken thigh to $2700 \mathrm{mg}$ per $\mathrm{kg}$ of pork shoulder depending on the type of muscle [47]. Their antioxidant properties are believed to arise through radical scavenging and metal chelation abilities [48]. The presence of thiol groups and aromatic side chains (tryptophan, tyrosine and phenyl alanine) and imidazole ring in histidine $[49,50]$ are recognized as important structural features for their antioxidant properties. Casein derived peptides from milk proteins have been reported to inhibit enzymatic as well as non-enzymatic oxidation of lipids [51,52]. Generation of antioxidative peptides from milk proteins has been studied in detail [53]. Antioxidant peptides from egg proteins have also been reported [54,55]. Apart from proteins, other antioxidant compounds in animal tissues such as vitamin $\mathrm{E}$ and ascorbic acid are well-known for their antioxidant properties [56]. Some aquatic animals including salmon and shrimp contain high amounts of carotenoids with strong antioxidant properties. Astaxanthin, a carotenoid found in high concentrations in fish and shrimp, showed strong singlet oxygen and radical scavenging ability, which was 100 times greater than $\alpha$-tocopherol activity [57]. The activity was mainly attributable to the presence of hydroxyl and keto endings on each ionone ring in the structure of astaxanthin [58].

\section{Egg as an Antioxidant Food Commodity}

\subsection{Chemical and Nutritional Composition of Eggs}

Egg is composed of three parts: egg shell with membranes, egg white albumen, and yolk, accounting for approximately $9.5 \%, 63 \%$ and $27.5 \%$ of the whole shell egg [59]. The edible portion of the egg consists of water $(74 \%)$, proteins $(12 \%)$, lipids $(12 \%)$, carbohydrate $(<1 \%)$ as well as vitamins and minerals [60]. The chemical and nutrient composition of egg is well documented [60-63]. The protein fraction is distributed in both egg white (ovalbumin, ovotransferrin, ovomucoid, ovomucin, etc.) and yolk (high density lipoproteins, low density lipoproteins and livetins). Eggs proteins are high quality proteins and are used as a golden standard for measuring the quality of other food proteins [61]. Almost all egg lipids are located in yolk and approximately $65 \%$ of yolk lipids are triglycerides, while phospholipids, cholesterol and carotenoids make $30 \%, 4 \%,<1 \%$, respectively [64]. The fatty acid composition of egg yolk can be manipulated through feed formulation to produce eggs enriched with polyunsaturated fatty acids with benefits beyond basic nutrition [65]. Based on the standardized poultry feed, about 30\%-35\% from the total fatty acids are saturated fatty acids (SFA), 
$40 \%-45 \%$ are monounsaturated fatty acids (MUFA), and $20 \%-25 \%$ are polyunsaturated fatty acids (PUFA) [66]. Egg yolk lipids have been used as a source of long-chain polyunsaturated fatty acids, Docosahexaenoic acid (DHA) and phospholipids to incorporate into infant formula $[67,68]$. Eggs are also considered a good source of micronutrients such as vitamins and minerals. Eggs contain $\sim 16 \%, 29 \%, 9 \%$ and $9 \%$ of the recommended daily intake (RDI) of phosphorus, selenium, iron, and zinc, and $10 \%$ of the RDI of vitamin A, D, E, K, B2, B12, biotin and pantothenic acid [61]. It has been shown that some minerals like selenium, and iodine can be enriched through fortification of feed $[69,70]$. In the same way as minerals, vitamin contents of egg can be manipulated through hen's feed formulation [71].

In addition to the nutritional value, egg components have various biological activities which may render important health benefits [72]. Egg is a complete biological system designed to nourish and protect the growing embryo from various pathogen invasions. As a result, egg shell with membranes and egg white proteins possess physical and biological defense mechanisms such as viscosity, $\mathrm{pH}$, antimicrobial properties, etc. For a list of egg compounds with various bioactivities please refer to [62] and [73].

\subsection{Antioxidant Compounds in Eggs}

Numerous compounds in both egg white and yolk exhibit antioxidant properties (Table 1). Many egg proteins such as ovalbumin, ovotransferrin, phosvitin, egg lipids such as phospholipids, as well as certain micronutrients such as vitamin E, vitamin A, selenium, and carotenoids, are reported to have antioxidant properties. In addition, eggs can be further enriched with antioxidants (i.e., carotenoids, vitamin E, selenium and iodine) through manipulation of poultry feed [58-61].

Table 1. Antioxidants in Egg.

\begin{tabular}{|c|c|c|}
\hline Name of Compound & Amount in Egg & Mechanisms of Action \\
\hline Egg white & (\% of egg white proteins) & \\
\hline Ovalbumin & 54 & $\begin{array}{l}\text { Free thiol }(\mathrm{SH}) \text { groups in ovalbumin regulate } \\
\text { the redox status and bind metal ions, thereby } \\
\text { exert antioxidant properties [74]; Increased } \\
\text { antioxidant activity when conjugated with } \\
\text { saccharides }[74,75]\end{array}$ \\
\hline Ovotransferrin & 12 & $\begin{array}{l}\text { Possess SOD-like superoxide scavenging } \\
\text { activity due to its metal chelating ability [76] }\end{array}$ \\
\hline Ovomucin & 3.5 & $\begin{array}{l}\text { Inhibit } \mathrm{H}_{2} \mathrm{O}_{2} \text {-induced oxidative stress in } \\
\text { human embryonic kidney [77] }\end{array}$ \\
\hline Lysozyme & 3.4 & $\begin{array}{l}\text { Suppress reactive oxygen species (ROS) and } \\
\text { oxidative stress genes [78] }\end{array}$ \\
\hline Cystatin & 0.05 & $\begin{array}{l}\text { Modulate the synthesis and release of } \mathrm{NO}^{\bullet} \\
\text { production and thereby play a role in cellular } \\
\text { antioxidant pathways }[79,80]\end{array}$ \\
\hline Egg yolk & (\% of yolk dry matter) & \\
\hline Phosvitin & 4 & $\begin{array}{l}\text { Antioxidant activity based on metal chelating } \\
\text { ability; chelates iron and protects against } \\
\text { Fe-induced oxidative damage }[81,82]\end{array}$ \\
\hline Phospholipids & 10 & $\begin{array}{l}\text { Hydrolyl amines in the side chains of } \\
\text { phospholipids play a role in radical } \\
\text { scavenging and exert antioxidant } \\
\text { properties [83] }\end{array}$ \\
\hline Carotenoids & $<1$ & $\begin{array}{l}\text { Unsaturated backbone and aromatic rings of } \\
\text { carotenoids aid in neutralizing singlet oxygen } \\
\text { and free radicals and protect against oxidative } \\
\text { damage }[22,25,26]\end{array}$ \\
\hline
\end{tabular}


Table 1. Cont.

\begin{tabular}{cll}
\hline Name of Compound & Amount in Egg & \multicolumn{1}{c}{ Mechanisms of Action } \\
\hline & $<1$ & $\begin{array}{l}\text { Vitamin E can donate its phenolic } \\
\text { hydrogen to scavenge free radicals [15]; } \\
\text { protect membrane fatty acids and plasma } \\
\text { Low density lipoproteins (LDL), High } \\
\text { density lipoproteins (HDL) against lipid } \\
\text { oxidation [84] }\end{array}$ \\
\hline \multirow{2}{*}{ Aromatic amino acids } & $<1$ & $\begin{array}{l}\text { Aromatic nature of tryptophan and } \\
\text { tyrosine contribute to the total antioxidant } \\
\text { capacity [85] }\end{array}$ \\
\hline
\end{tabular}

\subsubsection{Antioxidants Naturally Occurring in Eggs}

Ovalbumin

Ovalbumin is a glycoprotein made of 385 amino acids and constitutes approximately $54 \%(\mathrm{w} / \mathrm{w})$ of the total egg white protein $[60,86]$. It contains six cysteine residues with a single disulfide bond and is the only egg white protein with free SH (thiol) groups [60]. The presence of thiol groups enable its ability to play a role in redox regulation and binding metal ions therefore exert antioxidant properties [87-89]. In 1971, Goto and Shibasaki observed the protective effects of ovalbumin against lipid oxidation in a linolenic model system [90]. When covalently attached with polysaccharides, the radical scavenging activity of ovalbumin was significantly increased [74]. It was speculated that free SH groups are responsible for the antioxidant activity of ovalbumin, which were effectively exposed upon the conjugation with polysaccharides [74]. Further studies on glycated ovalbumin showed that the activity is dependent on the type of sugars used and also the configuration of hydroxyl groups in the sugar molecule $[75,91]$.

\section{Ovotransferrin}

Ovotransferrin (also known as conalbumin), representing $12 \%-13 \%$ of the total egg white protein, is a member of the transferrin family, a group of ion-binding proteins with an in vivo preference for iron [60,92]. Ovotransferrin consists of two lobes, each capable of binding one atom of $\mathrm{Fe}^{3+}$ and carbonate anion [60]. Among the two, the $\mathrm{N}$-lobe is found to be more important for its antioxidant properties [76].

Ovotransferrin was reported to possess SOD-like activity against superoxide anion promoted by metal binding. The scavenging activity was dose-dependent and considerably higher than known for antioxidants such as ascorbate or serum albumin [76]. Additionally, the iron-binding ability of ovotransferrin has an indirect role in preventing iron-induced lipid peroxidation [60].

\section{Lysozyme}

Lysozyme is an enzyme present in almost all organisms. One egg contains approximately $0.3-0.4 \mathrm{~g}$ of lysozyme [93]. Lysozyme is a defensin, a member of the family of native, highly conserved host-defense proteins [78]. It contains an 18-amino acid domain that binds agents such as advanced glycation end products (AGE), which contribute to the production of ROS and increased oxidative stress (ROS). Liu et al., showed that lysozyme protects transgenic mice against acute and chronic oxidative injury [78]. They also showed that hepatocytes incubated with lysozyme suppress cellular ROS levels and oxidative response genes. In another study, the survival rate following acute or chronic oxidative injury in lysozyme deficient transgenic mice was found to be significantly lower compared to the control, indicating its protective role as an antioxidant [94]. 
Cystatin

Egg white cystatin is the first identified member of the cystatin family [95]. It is a small protein of approximately $13 \mathrm{kDa}$ molecular weight which makes up $0.05 \%$ of the total egg white proteins and contains two disulfide bonds [60]. Cystatin is an inhibitor of cysteine proteinases, thereby exerting antibacterial properties [96,97]. It is also reported that chicken cystatin exerts immunomodulatory activities by modulating the synthesis and release of $\mathrm{NO}^{\bullet}$ production in interferon $\gamma$-activated murine macrophages [78-80,98,99]. Optimum levels of $\mathrm{NO}^{\bullet}$ is essential for regulation of certain cellular antioxidant pathways [100]. Moreover, cystatin B, the group which chicken cystatin belongs to, has recently found to involve in protecting cerebellar granule neurons from oxidative stress by playing a role in oxidative stress-responsive signaling pathway [79]. Taken together, the role of cystatin in modulating the $\mathrm{NO}^{\bullet}$ synthesis and protecting brain neurons from oxidative damage, provide us with evidence of its potential activity as an antioxidant.

\section{Ovoinhibitor}

Ovoinhibitor, which makes approximately $1.5 \%$ of egg white proteins, inhibits serine proteinases such as trypsin and chymotrypsin and also bacterial and fungal proteinases [93]. It was shown that chymotrypsin proteinase inhibitors including ovoinhibtor are capable of inhibiting the formation of ROS in activated human polymorphonuclear leukocytes during the inflammatory response [100]. They demonstrated that about $29 \%$ of formation of $\mathrm{H}_{2} \mathrm{O}_{2}$ was inhibited by ovoinhibitor at a concentration of $20 \mu \mathrm{M}$ [100].

\section{Phosvitin}

Phosvitin is the most phosphorylated protein containing nearly $80 \%$ of yolk protein phosphorous and represents $\sim 11 \%$ of yolk proteins [101]. More than half of its amino acid composition is serine, which exists as phosphoserine. It has a strong metal-binding ability and approximately $95 \%$ of yolk iron is bound to phosvitin. This high metal-binding capacity makes phosvitin a potential antioxidant, particularly against iron induced oxidative damage [82]. Iron is essential for life; under normal physiological conditions, the level is controlled by iron binding proteins ferritin and transferrin. However, if the balance is disturbed causing iron overload in cells, the effects could be lethal as humans have a very limited capacity to excrete excess iron. The excess iron in the form of $\mathrm{Fe}^{2+}$ can participate in Fenton reaction to produce toxic $\mathrm{OH}^{\bullet}$ by reacting with $\mathrm{H}_{2} \mathrm{O}_{2}$.

Moreover, the circulating free iron can oxidize heart-muscle membranes, causing arrhythmia and heart failure. The iron-chelating ability of phosvitin indicates its possible role in protecting iron-induced oxidative damage. Phosvitin accelerates $\mathrm{Fe}^{2+}$ autoxidation, thereby reducing the availability of $\mathrm{Fe}^{2+}$ and inhibiting $\mathrm{Fe}^{2+}$-catalyzed $\mathrm{OH}^{\bullet}$ generation through Fenton reaction [102]. Additionally, phosvitin is also proven to be effective against UV-induced lipid peroxidation in the presence of excess iron [103].

Phospholipids

Egg yolk phospholipids consist of $84 \%$ phosphatidylcholine (PC), $12 \%$ phosphatidylethanolamine (PE), 2\% sphingomyelin and 2\% lysophosphatidylcholine and other minor compounds [64]. King, Boyd, and Sheldon (1992) reported that egg yolk phospholipids exhibit antioxidant activity in a refined salmon oil model system, and also demonstrated that the presence of nitrogen improved the antioxidant activity of phospholipids [104]. The antioxidant activity was positively associated with the degree of fatty acid unsaturation [81]. Hydroxy amines in the side chains of choline and ethanolamines showed strong inhibition of lipid peroxidation, indicating the importance of side-chain amino acids with hydroxyl groups in the antioxidant activity [105]. 


\section{Carotenoids}

Carotenoids are lipid soluble compounds responsible for the orange-yellow color of the egg yolk. The health promoting properties of carotenoids are well documented [106,107]. More than 600 carotenoids have been identified to date and it is suggested than around 50 of them might occur in our diet and 14 in human blood [107,108]. Human body do not synthesize carotenoids and must be obtained through the diet. Therefore, it is important to consider the type and bioavailability of dietary carotenoids. Bioavailability of egg carotenoids is superior to those from green leafy vegetables $[109,110]$ due to the solubilization of yolk lipids, which makes eggs a unique and important carrier of bioactive carotenoids. The profile of egg carotenoids is largely depend on hen's feed composition, therefore it can vary among different types of eggs [111,112]. Certain carotenoids are allowed to use as poultry feed additives to improve color of the egg yolk, however, the amount and types of carotenoid can be varied as per the country's feed regulation [113]. In general, lutein, zeaxanthin, canthaxanthin, $\beta$-apo- $8^{\prime}$-carotenal, capsanthin, $\beta$-apo- 8 '-carotenoic acid ethyl ester, $\beta$-cryptoxanthin, and citranaxanthin can be present in egg yolk [114].

Human plasma contains several carotenoids including $\beta$-carotene, $\alpha$-carotene, $\beta$-cryptoxanthin, lutein and zeaxanthin and their isomers [115]. Lutein, zeaxanthin and meso-zeaxanthin are the main components of the eye macular pigment [116]. Lutein and zeaxanthin are well known for their role in protecting the eye from age-related macular degeneration (AMD) [117]. The singlet oxygen and radical scavenging activity of lutein and zeaxanthin is considered one of the two major mechanisms for their beneficial effects against light-induced oxidative damage in eye macular, in particular, against AMD [117-119]. The other major mechanism is their ability to absorb blue light, particularly before it damages the photoreceptor cells, which is also considered a passive antioxidant action [117]. A recent study demonstrated that pre-incubation of human lens epithelial cells (HLEC) with lutein, zeaxanthin and $\alpha$-tocopherol, dramatically reduced the levels of $\mathrm{H}_{2} \mathrm{O}_{2}$-induced protein carbonyl, MDA, and DNA damage [120]. Further, lutein, zeaxanthin and $\alpha$-tocopherol supplementation increased GSH levels and GSH: GSSG ratio, particularly in response to oxidative stress [120]. Dietary supplementation with lutein reduced plasma lipid hydroperoxides and the size of aortic lesions in mice [121] and reduced the plasma levels of oxidized-LDL in guinea pigs [122], indicating a protective role in ROS induced early atherosclerosis. The ability of lutein and zeaxanthin to scavenge hydroxyl and superoxide radicals is attributed to the presence of double bonds which makes a bond with the free radical to produce a highly resonance-stabilized C-centered radical [123]. Lutein, zeaxanthin and $\beta$-cryptoxanthin have also been shown to scavenge peroxynitrite which may play a role in LDL protection against oxidative damage [124].

\section{Vitamins and Minerals}

On average egg contains around $1.1 \mathrm{mg}$ of vitamin E [61] which is equivalent to $8.5 \%$ of RDA. Vitamin E, especially $\alpha$-tocopherol as the most active form, is a well-known lipophilic chain-breaking antioxidant known to protect long-chain polyunsaturated fatty acids in the membranes of cells and thus maintain their bioactivity $[125,126]$. In plasma, vitamin E exists with LDL and HDL, providing protection against oxidation [84,127]. Supplementing with vitamin E increased resistance to LDL-oxidation and is associated with a lower risk of coronary diseases in both men [128] and women [129]. Eggs can be enriched with vitamin E to provide up to 150\% RDA without formation of off flavour [130], not only providing the aforementioned benefits, but also protecting against oxidation of long chain fatty acids in yolk [130].

Certain minerals present in egg yolk including selenium and iodine also contribute to the antioxidant properties. Selenium is an essential mineral present in antioxidant selenoproteins such as GPx, thioredoxin reductases (TrxR) and selenoprotein P (Sepp1) [131]. Iodine has a potential role as an antioxidant in human systems including the eye, thyroid and the breast [132]. Iodine deficiency can increase the stimulation of thyroid gland by TSH resulting in excessive $\mathrm{H}_{2} \mathrm{O}_{2}$ [132]. 
Egg-Derived Antioxidative Peptides

Antioxidant activity was reported from egg white and egg yolk proteins. Recently, many studies have reported antioxidant properties of egg white proteins hydrolyzed using different enzymes and some have even purified the potential antioxidant peptides [133-136]. For example, Liu et al., used alcalase to produce and purified three novel peptides with antioxidant properties, DHTKE (Asp-His-Thr-Lys-Glu), FFGFN (Phe-Phe-Glu-Phe-His) and MPDAHL (Met-Pro-Asp-Ala-His-Leu) [137]. Similarly, our recent studies showed that "protease P" hydrolysed egg white produce twopotent antioxidant peptides, AEERYP (Ala-Glu-Glu-Arg-Tyr-Pro) and DEDTQAMP (Asp-Glu-Asp-Thr-Gln-Ala-Met-Pro) [138]. Trypsin hydrolysate prepared from egg white protein precipitate, obtained as a by-product in cystatin and lysozyme isolation, showed a considerably better radical scavenging activity than those prepared from chymotrypsin and elastase $[139,140]$. Adult male spontaneously hypertensive rats fed with peptic digested egg white for 17 weeks showed increased radical-scavenging capacity of the plasma and lowered MDA concentration in the aorta, and exerted a beneficial effect on the lipid profile, lowering triglycerides and total cholesterol without changing HDL levels [141]. Two peptides derived from lecithin-free egg yolk exhibit protection against lipid peroxidation in intoxicated normal human liver cells [142]. Both peptides contained a leucine residue at their $N$-terminal positions which were thought to contribute to their antioxidant properties [142]. Another study showed that egg yolk protein hydrolysate exhibited superoxide and hydroxyl radical scavenging activity, effectively inhibiting thiobarbituric acid reactive substances (TBARS) formation from ground beef and tuna homogenates, indicating its potential as a natural antioxidant [143].

The peptide, Tyr-Ala-Glu-Glu-Arg-Tyr-Pro-Ile-Leu, derived from pepsin hydrolyzed ovalbumin, which was previously reported to possess angiotensin converting enzyme (ACE)-inhibitory activity, also exhibited a strong radical scavenging activity and delayed the LDL-oxidation induced by $\mathrm{Cu}^{2+}$ [54]. Peptic digests of ovalbumin inhibited the action of $\mathrm{OH}^{\bullet}$ and $\mathrm{O}_{2}{ }^{\bullet-}$ and also prevented the oxidation of linoleic acid in linoleic acid autoxidation system [144]. In-vivo studies showed that supplementation with these peptic digests of ovalbumin significantly decreased the production of oxidants and oxidative damage in serum and liver of aged mice [144].

Enzymatic hydrolysis of ovotransferrin was shown to lead to enhanced overall antioxidant activity. Two tetrapeptides (Trp-Asn-Ile-Pro and Gly-Trp-Asn-Ile) were characterized from thermolytic hydrolysate of ovotransferrin [145]. Trp-Asn-Ile was suggested as the responsible peptide motif for the high activity of the above tetrapeptides [146]. A tripeptide Ile-Arg-Trp, derived from ovotransferrin showed strong radical scavenging activity which was attributed to tryptophan and the peptide bond between Trp and Arg [146]. It is known that Trp can exert radical scavenging properties mainly due to the presence of the indole ring $[147,148]$. A recent study demonstrated that grafting a catechin moiety significantly increased the antioxidant activity of ovotransferrin implicating its potential as neutraceutical and functional food [149]. Peptides derived from lysozyme are reported to possess antioxidant properties [150-152].

Egg white ovomucin, a sulfated glycoprotein accounting for $3.5 \%-4 \%$ of egg white proteins, is responsible for the jelly-like structure of egg white $[60,153]$. Recently, ovomucin derived pentapeptide Trp-Asn-Trp-Ala-Asp was reported to reduce $\mathrm{H}_{2} \mathrm{O}_{2}$-induced oxidative stress in human embryonic kidney (HEK-293) cells by inhibiting intracellular ROS accumulation and blocking the ROS activated mitochondria-mediated cell apoptosis pathway [154]. Others also reported on antioxidant properties of peptides derived from ovomucin [75,134].

Phosvitin phosphopeptides (PPP) obtained from tryptic digestion of egg yolk phosvitin showed protective effects against $\mathrm{H}_{2} \mathrm{O}_{2}$-induced oxidative stress in human intestinal epithelial cells $[155,156]$. The antioxidative activity of PPP was similar to that of glutathione and positively related to the phosphorous content. PPPs are also assumed to be involved with up-regulating glutathione and associated antioxidative enzymes such as glutathione reductase, glutathione $S$-transferase, and 
catalase and thus reducing the oxidative stress [157]. Furthermore, the antioxidative activity of PPPs on $\mathrm{H}_{2} \mathrm{O}_{2}$-induced oxidative stress retained after gastrointestinal digestion [81].

\subsubsection{Antioxidant Enriched Eggs}

Owing to its high lipid content, many lipid-soluble antioxidant compounds such as lutein/zeaxanthin, vitamin E, selenium, iodine lycopene can be incorporated into egg yolk [158]. The most studied are omega-3 fatty acids, which are incorporated into eggs by feeding fish oil, flax seed, algae, or other ingredients to laying hens [159]. High contents of omega-3 fatty acids might increase susceptibility to fatty acid oxidation therefore simultaneously enrichment of eggs with antioxidants such as vitamin $\mathrm{E}$ and carotenoids was suggested to decrease fatty acid oxidation and provide a good source of dietary antioxidant [158].

Carotenoids are naturally occurring in egg yolk in varied amounts depending on hen's feed. Feed fortification with natural sources such as marigold (Tagetes erecta) or alfalfa (Medicago sativa) extracts are sources of lutein, while other sources such as corn (Zea mays) and red pepper (Capsicum annuum) provide zeaxanthin and capsanthin respectively [113,160]. Canthaxanthin, $\beta$-apo- $8^{\prime}$-carotenal and $\beta$-apo- 8 -carotenoic acid ethyl ester are chemically synthesized and incorporated into the feed [114]. Lutein and zeaxanthin are two major egg carotenoids that can be found in human serum, skin and eye macular and involved in the protective roles against oxidative stress [161,162]. Lutein content of enriched eggs can be increased up to 15-fold compared to the control group, for example enriched egg contains around $1.9 \mathrm{mg}$ of lutein [130]. Lutein enriched eggs show a higher lutein bioavailability compared to lutein, lutein ester supplements, and spinach [110]. Lycopene is a hydrocarbon carotenoid reported to have strong antioxidant properties effective in reducing the risk of prostate carcinoma [163,164]. Although lycopene is not usually found in eggs, lycopene enrichment can be achieved via feed fortification with tomato powder and lycopene could reduce yolk lipid peroxidation [165].

Vitamin $\mathrm{E}$ is the major lipophilic antioxidant compound in our body that may provide the primary protection against free radical induced lipid peroxidation [125]. The daily requirement is approximately $15 \mathrm{mg} \alpha$-tocopherol equivalents per day [166]. Since vitamin E is needed to protect membrane lipids from being peroxidized, this amount can be increased with higher intake of polyunsaturated fatty acids $[167,168]$. Egg can be enriched to provide around $20 \mathrm{mg}$ of vitamin E per egg, which is more than the daily requirement, and also provide protection against unsaturated fatty acid peroxidation [158]. Folate, a water soluble B-group vitamin is shown to reduce the incidence of neural tube defects in newborns [169]. Egg yolk can be enriched with highly bioavailable folate through fortification of feed with folic acid to provide up to $12.5 \%$ of the recommended daily intake of folate $[170,171]$. Almost all the folate in egg exists in the form of 5-methyltetrahydrofolate (5-MTHF), and showed high stability during cooking [172]. Folates are reported to have antioxidant properties and among different forms, 5-MTHF was reported to have the most prominent antioxidant activity, which was attributed to the electron donating effect of the 5-amino group [173]. In vivo and ex vivo studies with human vessels showed that 5-MTHF improves NO-mediated endothelial function, decreases superoxide production, scavenge peroxynitrite and also reversed endothelial nitric oxide synthase (eNOS) uncoupling, thereby exerts antioxidant effects [174,175].

Both selenium and iodine, which are known to have antioxidant properties, can be effectively transferred into the egg yolk. Eggs can be supplemented to provide up to $50 \%$ and $150 \%$ of the daily requirements of selenium and iodine respectively $[158,176]$. Collectively, these antioxidant enriched eggs provide multiple advantages by serving as a dietary source of several nutrients including omega 3, vitamin E, vitamin D, selenium, iodine and also as an important source of antioxidants such as lutein. 


\subsection{Effect of Processing, Storage Conditions and Gastrointestinal Digestion on Egg Antioxidants}

Foods are subjected to various processing and storage conditions before consumption, which may influence the antioxidant capacity of food components. The effect of food processing and storage conditions on the overall antioxidant activity of a particular food is a result of several different events occurring consecutively or simultaneously. According to Nicoli et al., there are three possible effects of food processing on the overall antioxidant capacity [177]:

1 The total antioxidant capacity is not affected: as a result of no changes in natural antioxidant compounds or loss of naturally occurring antioxidants balanced by formation of compounds with novel or improved antioxidant properties,

2 The total antioxidant capacity is increased: as a result of improvement of antioxidant properties of naturally occurring compounds or formation of new antioxidant,

3 The total antioxidant capacity is decreased: loss of naturally occurring antioxidants or formation of new compounds with pro-oxidant activity.

Most thermal processing methods can create environments that can lead to oxidation, thermal degradation, and leaching of vitamin $C$ and phenolic compounds, which would reduce the antioxidant activity [178]. With regard to carotenoids, processing can lead to the dissociation of compounds from plant matrix resulting in increased carotenoid antioxidants, and improved digestive absorption [179-181]. Most of the fruits and vegetables contain phenolic compounds, carotenoids and vitamin $C$, which are differently affected by processing conditions. Consequently, the total antioxidant capacity can be increased [182-184] or decreased [184-187]. In animal-derived foods, the antioxidant capacity depends mainly on amino compounds (proteins, peptides and amino acids) and vitamin $\mathrm{E}$.

Heat modification of egg white proteins, ovalbumin, lysozyme and ovomucoid via Maillard reaction resulted in protein-sugar conjugates, leading to increased radical scavenging properties [188]. Chen, Chi, and $\mathrm{Xu}$ showed that there are no significant differences in terms of DPPH (1,1-diphenyl-2-picrylhydrazyl) radical-scavenging activity, reducing power, and lipid peroxidation inhibitory activity of spray dried and freeze-dried egg white protein hydrolysates compared to the undried sample [135]. Antioxidant properties of egg yolk phosvitin is due to its iron binding abilities; heating phosvitin at $110^{\circ} \mathrm{C}$ for $40 \mathrm{~min}$ did not change the iron binding ability of phosvitin [189].

Carotenoids and vitamin E in egg yolk are reported to be influenced by thermal processing. In the presence of heat, light, oxygen, etc., carotenoids can undergo trans-cis isomerization, or they can be degraded resulting in altered or loss of bioactivity [190]. Boiling of eggs resulted in a $10 \%-20 \%$ carotenoid loss [112], whereas pasteurizarion did not change the carotenoid content [191]. Storage conditions such as temperature can also affect the antioxidant properties of eggs. Storage at refrigeration temperature for two weeks reduced significantly the total carotenoid content in raw eggs enriched with omega-3 and carophyll (canthaxanthin preparation), while at room temperature, the losses were observed after 7 days of storage [192]. The vitamin E content of eggs was also significantly reduced by thermal processing accompanied with increased lipid oxidation products [193,194].

Pretreatments with ultrasound, high-intensity pulsed electric field (PEF) or high pressure can affect the antioxidant activity of egg proteins/peptides. Pretreatment with PEF significantly increased the antioxidant activity of egg white protein hydrolysate which was attributed to the release of free amino acids and small peptides with antioxidant properties [134]. Also, high pressure processing and sonication or ultrasound pretreatments are shown to improve the degree of hydrolysis of egg white proteins which result increased antioxidant properties [195,196].

Gastrointestinal digestion involves extreme $\mathrm{pH}$ conditions and various enzymes which might cause degradation of antioxidant componds or generation of novel antioxidant compounds. Many recent research activities have evaluated the changes in antioxidant capacity of different food products after gastrointestinal digestion using diverse model systems. After gastrointestinal digestion, the antioxidant activity of wheat [197], gooseberries [198], grapes [199], soymilk [200], 
saithe and shrimp [201] and loach protein hydrolysate [202] increased several times, attributed mainly to increased free amino acid content and short chain peptides generated during digestion. However, the antioxidant activity of some foods such as apples [203] and Feijoada whole meal (a traditional Brazilian dish containing vegetables) [204] was significantly reduced.

Many studies have reported the formation of antioxidant peptides after simulated gastrointestinal digestion of egg components [81,134,150]. A recent study showed that different types of domestic cooking methods such as boiling and frying decreased the antioxidant activity [134]. Nevertheless, simulated gastrointestinal digestion of cooked egg with pepsin and pancreatin significantly increased the antioxidant activity, which was attributed to the release of amino acids and antioxidant peptides [134]. Our recent studies on effect of simulated gastrointestinal digestion of egg yolk antioxidant using highly sophisticated intestinal model TIM-1 showed that, lutein and zeaxanthin, the main egg carotenoids, remain stable during the gastrointestinal digestion and also highly bioaccessible possibly due to the association with yolk fat [205], it is likely that they retain their antioxidant activity. Moreover, gastrointestinal digestion significantly increased the total antioxiant activity of cooked egg yolk (about 5-8 fold), which is presumed to be a result of increased free amino acid content and release of antioxidant peptides

\section{Summary}

Oxidative stress is hypothesized to be responsible for the onset and development of various diseases and ageing. Dietary antioxidants are thought to impart potential benefits in reducing the risk of some chronic diseases by maintaining redox homeostasis. There is extensive research on the presence and characterization of antioxidants from fruits, vegetables, cereals and herbs; however, there is only limited research with regard to antioxidants from animal products. Eggs are an important part of our breakfast and an excellent source of high quality proteins, lipids, vitamins and minerals. Many egg proteins such as ovalbumin, ovotransferrin, phosvitin, and egg lipids such as phospholipids, as well as certain micronutrients such as vitamin E, vitamin A, selenium, and carotenoids, are reported to have antioxidant properties. Furthermore, eggs can be enriched with antioxidants (i.e., carotenoids, vitamin E, selenium and iodine) through manipulation of poultry feed. Domestic cooking tended to reduce the antioxidant activity of egg, while gastrointestinal digestion of cooked eggs increased the antioxidant due to the release of amino acid and peptides.

Acknowledgments: This review was funded by grants from Egg Farmers of Canada (EFC), Alberta Egg Producers (AEP), the Agriculture and Food Council, which is responsible for delivering Agriculture and Agri-Food Canada's Advancing Canadian Agriculture and Agri-Food (ACAAF) Program in Alberta, Food for Health Initiative (Vitamin Fund) of the Faculty of Agricultural, Life and Environmental Science of the University of Alberta, Burnbrae Farms Limited, Poultry Industry Council and Natural Sciences and Engineering Research Council (NSERC) of Canada to Jianping Wu.

Author Contributions: Jianping Wu and Chamila Nimalaratne generated the concept of review. Chamila Nimalaratne drafted the manuscript and Jianping Wu reviewed and edited the manuscript.

Conflicts of Interest: The authors declare no conflict of interest.

\section{References}

1. Halliwell, B. Biochemistry of oxidative stress. Biochem. Soc. Trans. 2007, 35, 1147-1150. [PubMed]

2. Khlebnikov, A.I.; Schepetkin, I.A.; Domina, N.G.; Kirpotina, L.N.; Quinn, M.T. Improved quantitative structure-activity relationship models to predict antioxidant activity of flavonoids in chemical, enzymatic, and cellular systems. Bioorganic Med. Chem. 2007, 15, 1749-1770.

3. Carocho, M.; Ferreira, I.C.F.R. A review on antioxidants, prooxidants and related controversy: Natural and synthetic compounds, screening and analysis methodologies and future perspectives. Food Chem. Toxicol. 2013, 51, 15-25. [CrossRef] [PubMed]

4. Rizzo, A.M.; Berselli, P.; Zava, S.; Montorfano, G.; Negroni, M.; Corsetto, P.; Berra, B. Endogenous antioxidants and radical scavengers. Adv. Exp. Med. Biol. 2010, 698, 52-67. [PubMed] 
5. Lobo, V.; Patil, A.; Phatak, A.; Chandra, N. Free radicals, antioxidants and functional foods: Impact on human health. Pharmacogn. Rev. 2010, 4, 118-126. [CrossRef] [PubMed]

6. Brewer, M.S. Natural antioxidants: Sources, compounds, mechanisms of action, and potential applications. Compr. Rev. Food Sci. Food Saf. 2011, 10, 221-247. [CrossRef]

7. Matés, J.M.; Pérez-Gómez, C.; de Castro, I.N. Antioxidant enzymes and human diseases. Clin. Biochem. 1999, 32, 595-603. [CrossRef]

8. Rodriguez, C.; Mayo, J.C.; Sainz, R.M.; Antolin, I.; Herrera, F.; Martin, V.; Reiter, R.J. Regulation of antioxidant enzymes: A significant role for melatonin. J. Pineal Res. 2004, 36, 1-9. [PubMed]

9. Littarru, G.P.; Tiano, L. Bioenergetic and antioxidant properties of coenzyme q10: Recent developments. Mol. Biotechnol. 2007, 37, 31-37. [CrossRef] [PubMed]

10. Ames, B.N.; Cathcart, R.; Schwiers, E.; Hochstein, P. Uric acid provides an antioxidant defense in humans against oxidant- and radical-caused aging and cancer: A hypothesis. Proc. Natl. Acad. Sci. USA 1981, 78, 6858-6862. [CrossRef] [PubMed]

11. Halliwell, B. Antioxidants in human health and disease. Annu. Rev. Nutr. 1996, 16, 33-50. [CrossRef] [PubMed]

12. Halliwell, B. Free radicals and antioxidants: Updating a personal view. Nutr. Rev. 2012, 70, $257-265$. [CrossRef] [PubMed]

13. Sies, H. Oxidative stress: Oxidants and antioxidants. Exp. Physiol. 1997, 82, 291-295. [CrossRef] [PubMed]

14. Valko, M.; Leibfritz, D.; Moncol, J.; Cronin, M.T.D.; Mazur, M.; Telser, J. Free radicals and antioxidants in normal physiological functions and human disease. Int. J. Biochem. Cell Biol. 2007, 39, 44-84. [CrossRef] [PubMed]

15. Gülçin, İ. Antioxidant activity of food constituents: An overview. Arch. Toxicol. 2012, 86, 345-391. [CrossRef] [PubMed]

16. Vandghanooni, S.; Forouharmehr, A.; Eskandani, M.; Barzegari, A.; Kafil, V.; Kashanian, S.; Dolatabadi, J.E.N. Cytotoxicity and DNA fragmentation properties of butylated hydroxyanisole. DNA Cell Biol. 2013, 32, 98-103. [CrossRef] [PubMed]

17. Williams, G.; Iatropoulos, M.; Whysner, J. Safety Assessment of butylated hydroxyanisole and butylated hydroxytoluene as antioxidant food additives. Food Chem. Toxicol. 1999, 37, 1027-1038. [CrossRef]

18. Halliwell, B.; Murcia, M.A.; Chirico, S.; Aruoma, O.I. Free radicals and antioxidants in food and in vivo: What they do and how they work. Crit. Rev. Food Sci. Nutr. 1995, 35, 7-20. [PubMed]

19. Samaranayaka, A.G.P.; Li-Chan, E.C.Y. Food-derived peptidic antioxidants: A review of their production, assessment, and potential applications. J. Funct. Foods 2011, 3, 229-254. [CrossRef]

20. Sikora, E.; Cieślik, E.; Topolska, K. The sources of natural antioxidants. Acta Sci. Pol. Technol. Aliment. 2008, 7, 5-17.

21. Niki, E. Role of vitamin $\mathrm{E}$ as a lipid-soluble peroxyl radical scavenger: In vitro and in vivo evidence. Free Radic. Biol. Med. 2014, 66, 3-12. [CrossRef] [PubMed]

22. Stahl, W.; Sies, H. Antioxidant activity of carotenoids. Mol Aspect Med. 2003, 24, 345-351. [CrossRef]

23. Tang, G. Lycopenes and related 351.compounds. In Encyclopedia of Human Nutrition, 3rd ed.; Caballero, B., Ed.; Academic Press: Waltham, MA, USA, 2013; pp. 124-130.

24. Alves-Rodrigues, A.; Shao, A. The science behind lutein. Toxicol. Lett. 2004, 150, 57-83. [CrossRef] [PubMed]

25. Ma, L.; Lin, X.-M. Effects of lutein and zeaxanthin on aspects of eye health. J. Sci. Food Agric. 2010, 90, 2-12. [CrossRef] [PubMed]

26. Zhang, L.-X.; Cooney, R.V.; Bertram, J.S. Carotenoids enhance gap junctional communication and inhibit lipid peroxidation in $\mathrm{C} 3 \mathrm{H} / 10 \mathrm{~T} 1 / 2$ cells: Relationship to their cancer chemopreventive action. Carcinogenesis 1991, 12, 2109-2114. [CrossRef] [PubMed]

27. Procházková, D.; Boušová, I.; Wilhelmová, N. Antioxidant and prooxidant properties of flavonoids. Fitoterapia 2011, 82, 513-523. [CrossRef] [PubMed]

28. Benzie, I.F.F.; Choi, S.-W. Chapter One-Antioxidants in food: Content, measurement, significance, action, cautions, caveats, and research needs. Adv. Food Nutr. Res. 2014, 71, 1-53. [PubMed]

29. Fang, Y.-Z.; Yang, S.; Wu, G. Free radicals, antioxidants, and nutrition. Nutrition 2002, 18, 872-879. [CrossRef] 
30. Rice-Evans, C.; Miller, N.; Paganga, G. Structure-antioxidant activity relationships of flavonoids and phenolic acids. Free Radic. Biol. Med. 1996, 20, 933-956. [CrossRef]

31. Brunetti, C.; di Ferdinando, M.; Fini, A.; Pollastri, S.; Tattini, M. Flavonoids as antioxidants and developmental regulators: Relative significance in plants and humans. Int. J. Mol. Sci. 2013, 14, 3540-3555.

32. Duthie, G.; Crozier, A. Plant-derived phenolic antioxidants. Curr. Opin. Lipidol. 2000, 11, 43-47. [CrossRef] [PubMed]

33. Abourashed, E. Bioavailability of plant-derived antioxidants. Antioxidants 2013, 2, 309-325. [CrossRef]

34. Re, R.; Pellegrini, N.; Proteggente, A.; Pannala, A.; Yang, M.; Rice-Evans, C. Antioxidant activity applying an improved ABTS radical cation decolorization assay. Free Radic. Biol. Med. 1999, 26, 1231-1237. [CrossRef]

35. Rice-evans, C.A.; Miller, N.J.; Bolwell, P.G.; Bramley, P.M.; Pridham, J.B. The relative antioxidant activities of plant-derived polyphenolic flavonoids. Free Radic. Res. 2009, 22, 375-383. [CrossRef]

36. Pokorný, J. Natural antioxidants for food use. Trends Food Sci. Technol. 1991, 2, 223-227. [CrossRef]

37. Kahkonen, M.P.; Hopia, A.I.; Vuorela, H.J.; Rauha, J.P.; Pihlaja, K.; Kujala, T.S.; Heinonen, M. Antioxidant activity of plant extracts containing phenolic compounds. J. Agric. Food Chem. 1999, 47, 3954-3962. [CrossRef] [PubMed]

38. Podsędek, A. Natural antioxidants and antioxidant capacity of Brassica vegetables: A review. LWT Food Sci. Technol. 2007, 40,1-11. [CrossRef]

39. Cao, G.; Sofic, E.; Prior, R.L. Antioxidant Capacity of Tea and Common Vegetables. J. Agric. Food Chem. 1996, 44, 3426-3431. [CrossRef]

40. Velioglu, Y.S.; Mazza, G.; Gao, L.; Oomah, B.D. Antioxidant activity and total phenolics in selected fruits, vegetables, and grain products. J. Agric. Food Chem. 1998, 46, 4113-4117. [CrossRef]

41. Chu, Y.; Sun, J.; Wu, X.; Liu, R. Antioxidant and antiproliferative activities of common vegetables. J. Agric. Food Chem. 2002, 50, 6910-6916. [CrossRef] [PubMed]

42. Dykes, L.; Rooney, L.W. Phenolic compounds in cereal grains and their health benefits. Cereal Food World 2007, 52, 105-111. [CrossRef]

43. Adom, K.K.; Liu, R.H. Antioxidant activity of grains. J. Agric. Food Chem. 2002, 50, 6182-6187. [CrossRef] [PubMed]

44. Van Hung, P. Phenolic compounds of cereals and their antioxidant capacity. Crit. Rev. Food Sci. Nutr. 2014. [CrossRef]

45. Fardet, A.; Rock, E.; Rémésy, C. Is the in vitro antioxidant potential of whole-grain cereals and cereal products well reflected in vivo? J. Cereal Sci. 2008, 48, 258-276. [CrossRef]

46. Pérez-Jiménez, J.; Saura-Calixto, F. Literature data may underestimate the actual antioxidant capacity of cereals. J. Agric. Food Chem. 2005, 53, 5036-5040. [CrossRef] [PubMed]

47. Elias, R.J.; Kellerby, S.S.; Decker, E.A. Antioxidant activity of proteins and peptides. Crit. Rev. Food Sci. Nutr. 2008, 48, 430-441. [CrossRef] [PubMed]

48. Chan, K.M.; Decker, E.A. Endogenous skeletal muscle antioxidants. Crit. Rev. Food Sci. Nutr. 1994, 34, 403-426. [CrossRef] [PubMed]

49. Stadtman, E.R.; Levine, R.L. Free radical-mediated oxidation of free amino acids and amino acid residues in proteins. Amino Acids 2003, 25, 207-218. [CrossRef] [PubMed]

50. Atmaca, G. Antioxidant effects of sulfur-containing amino acids. Yonsei Med. J. 2004, 45, 776-788. [CrossRef] [PubMed]

51. Suetsuna, K.; Ukeda, H.; Ochi, H. Isolation and characterization of free radical scavenging activities peptides derived from casein. J. Nutr. Biochem. 2000, 11, 128-131. [CrossRef]

52. Sakanaka, S.; Tachibana, Y.; Ishihara, N.; Juneja, L.R. Antioxidant properties of casein calcium peptides and their effects on lipid oxidation in beef homogenates. J. Agric. Food Chem. 2005, 53, 464-468. [CrossRef] [PubMed]

53. Power, O.; Jakeman, P.; FitzGerald, R.J. Antioxidative peptides: Enzymatic production, in vitro and in vivo antioxidant activity and potential applications of milk-derived antioxidative peptides. Amino Acids 2013, 44, 797-820. [CrossRef] [PubMed]

54. Dávalos, A.; Miguel, M.; Bartolomé, B.; López-Fandiño, R. Antioxidant activity of peptides derived from egg white proteins by enzymatic hydrolysis. J. Food Prot. 2004, 67, 1939-1944. [PubMed] 
55. Huang, W.-Y.; Majumder, K.; Wu, J. Oxygen radical absorbance capacity of peptides from egg white protein ovotransferrin and their interaction with phytochemicals. Food Chem. 2010, 123, 635-641. [CrossRef]

56. Sies, H.; Stahl, W. Vitamins E and C, $\beta$-carotene, and other carotenoids as antioxidants. Am. J. Clin. Nutr. 1995, 62, 1315S-1321S. [PubMed]

57. Miki, W. Biological functions and activities of animal carotenoids. Pure Appl. Chem. 1991, 63, 141-146. [CrossRef]

58. Ngo, D.; Wijesekara, I.; Vo, T. Marine food-derived functional ingredients as potential antioxidants in the food industry: An overview. Food Res. Int. 2011, 44, 523-529. [CrossRef]

59. Cotterill, O.J.; Geiger, G.S. Egg product yield trends from shell eggs. Poult. Sci. 1977, 56, $1027-1031$. [CrossRef]

60. Li-Chan, E.C.Y.; Kim, H.O. Structure and chemical composition of eggs. In Egg Bioscience and Biotechnology; Mine, Y., Ed.; John Wiley \& Sons, Ltd: Hoboken, NJ, USA, 2008; pp. 1-95.

61. Seuss-baum, I. Nutritional evaluation of egg compounds. In Bioactive Egg Compounds; Huopalahti, R., Lopez-Fandino, R., Anton, M., Schade, R., Eds.; Springer-Verlag: Heidelbert, Germany; Berlin, Germany, 2007; pp. 117-144.

62. Kovacs-Nolan, J.; Phillips, M.; Mine, Y. Advances in the value of eggs and egg components for human health. J. Agric. Food Chem. 2005, 53, 8421-8431. [CrossRef] [PubMed]

63. United States Department of Agriculture. United States Department of Agriculture: National Nutrient Database for standard reference Release 27. Available online: http://ndb.nal.usda.gov/ndb/ (accessed on 25 September 2014).

64. Hatta, H.; Kapoor, M.; Juneja, L. Bioactive components in egg yolk. In Egg Bioscience and Biotechnology; Mine, Y., Ed.; John Wiley \& Sons, Ltd.: Hoboken, NJ, USA, 2008; pp. 185-237.

65. Surai, P.F. Effect of selenium and vitamin E content of the maternal diet on the antioxidant system of the yolk and the developing chick. Br. Poult. Sci. 2000, 41, 235-243. [CrossRef] [PubMed]

66. Anton, M. Composition and structure of hen egg yolk. In Bioactive Egg Compounds; Huopalahti, R., Lopez-Fandino, R., Eds.; Springer-Verlag: Heidelbert, Germany, 2007; pp. 17-24.

67. Carlson, S.; Montalto, M.; Ponder, D. Lower incidence of necrotizing enterocolitis in infants fed a preterm formula with egg phospholipids. Pediatr. Res. 1998, 44, 491-498. [CrossRef] [PubMed]

68. Hoffman, D.R.; Theuer, R.C.; Castaneda, Y.S.; Wheaton, D.H.; Bosworth, R.G.; O'Connor, A.R.; Morale, S.E.; Wiedemann, L.E.; Birch, E.E. Maturation of visual acuity is accelerated in breast-fed term infants fed baby food containing DHA-enriched egg yolk. J. Nutr. 2004, 134, 2307-2313. [PubMed]

69. Charoensiriwatana, W.; Srijantr, P.; Teeyapant, P.; Wongvilairattana, J. Consuming iodine enriched eggs to solve the iodine deficiency endemic for remote areas in Thailand. Nutr. J. 2010, 9, 68. [CrossRef] [PubMed]

70. Bourre, J.M.; Galea, F. An important source of omega-3 fatty acids, vitamins D and E, carotenoids, iodine and selenium: A new natural multi-enriched egg. J. Nutr. Health Aging 2006, 10, 371-376. [PubMed]

71. Naber, E.C. Modifying Vitamin Composition of Eggs: A Review. J. Appl. Poult. Res. 1993, 2, 385-393. [CrossRef]

72. Miranda, J.M.; Anton, X.; Redondo-Valbuena, C.; Roca-Saavedra, P.; Rodriguez, J.A.; Lamas, A.; Franco, C.M.; Cepeda, A. Egg and egg-derived foods: Effects on human health and use as functional foods. Nutrients 2015, 7, 706-729. [CrossRef] [PubMed]

73. Mine, Y.; D'Silva, I. Bioactive Components in Egg White. In Egg Bioscience and Biotechnology; Mine, Y., Ed.; John Wiley \& Sons, Inc.: Hoboken, NJ, USA, 2007; pp. 141-184.

74. Nakamura, S.; Kato, A.; Kobayashi, K. Enhanced antioxidative effect of ovalbumin due to covalent binding of polysaccharides. J. Agric. Food Chem. 1992, 40, 2033-2037. [CrossRef]

75. Huang, X.; Tu, Z.; Xiao, H.; Wang, H.; Zhang, L. Characteristics and antioxidant activities of ovalbumin glycated with different saccharides under heat moisture treatment. Food Res. Int. 2012, 48, 866-872. [CrossRef]

76. Ibrahim, H.; Hoq, M.; Aoki, T. Ovotransferrin possesses SOD-like superoxide anion scavenging activity that is promoted by copper and manganese binding. Int. J. Biol. Macromol. 2007, 41, 631-640. [CrossRef] [PubMed]

77. Chang, O.; Ha, G.; Han, G. Novel antioxidant peptide derived from the ultrafiltrate of ovomucin hydrolysate. J. Agric. Food Chem. 2013, 61, 7294-7300. [CrossRef] [PubMed] 
78. Liu, H.; Zheng, F.; Cao, Q.; Ren, B.; Zhu, L.; Striker, G.; Vlassara, H. Amelioration of oxidant stress by the defensin lysozyme. Am. J. Physiol. Endocrinol. Metab. 2006, 290, E824-E832. [CrossRef] [PubMed]

79. Lehtinen, M.K.; Tegelberg, S.; Schipper, H.; Su, H.; Zukor, H.; Manninen, O.; Kopra, O.; Joensuu, T.; Hakala, P.; Bonni, A.; et al. Cystatin B deficiency sensitizes neurons to oxidative stress in progressive myoclonus epilepsy, EPM1. J. Neurosci. 2009, 29, 5910-5915. [CrossRef] [PubMed]

80. Verdot, L.; Lalmanach, G.; Vercruysse, V.; Hartmann, S.; Lucius, R.; Hoebeke, J.; Gauthier, F.; Vray, B. Cystatins up-regulate nitric oxide release from interferon-gamma-activated mouse peritoneal macrophages. J. Biol. Chem. 1996, 271, 28077-28081. [CrossRef] [PubMed]

81. Young, D.; Nau, F.; Pasco, M.; Mine, Y. Identification of hen egg yolk-derived phosvitin phosphopeptides and their effects on gene expression profiling against oxidative stress-induced Caco-2 cells. J. Agric. Food Chem. 2011, 59, 9207-9218. [CrossRef] [PubMed]

82. Lu, C.-L.; Baker, R.C. Characteristics of egg yolk phosvitin as an antioxidant for inhibiting metal-catalyzed phospholipid oxidations. Poult. Sci. 1986, 65, 2065-2070. [CrossRef] [PubMed]

83. Sugino, H.; Ishikawa, M.; Nitoda, T.; Koketsu, M.; Juneja, L.R.; Kim, M.; Yamamoto, T. Antioxidative activity of egg yolk phospholipids. J. Agric. Food Chem. 1997, 45, 551-554. [CrossRef]

84. Ricciarelli, R.; Zingg, J.M.; Azzi, A. Vitamin E reduces the uptake of oxidized LDL by inhibiting cd36 scavenger receptor expression in cultured aortic smooth muscle cells. Circulation 2000, 102, 82-87. [CrossRef] [PubMed]

85. Nimalaratne, C.; Lopes-Lutz, D.; Schieber, A.; Wu, J. Free aromatic amino acids in egg yolk show antioxidant properties. Food Chem. 2011, 129, 155-161. [CrossRef]

86. Lechevalier, V.; Croguennec, T. Ovalbumin and gene-related proteins. In Bioactive Egg Compounds; Springer-Verlag: Berlin, Germany, 2007.

87. Deneke, S. Thiol-based antioxidants. Curr. Top. Cell. Regul. 2001, 36, 151-181.

88. Thomas, J.A.; Poland, B.; Honzatko, R. Protein sulfhydryls and their role in the antioxidant function of protein S-thiolation. Arch. Biochem. Biophys. 1995, 319, 1-9. [CrossRef] [PubMed]

89. Roos, G.; Messens, J. Protein sulfenic acid formation: From cellular damage to redox regulation. Free Radic. Biol. Med. 2011, 51, 314-326. [CrossRef]

90. Goto, M.; Shibasaki, K. Effect of oxidation of oils on deterioration of foods. II. Effect of food components on the oxidation of linoleic acid. Nihon Shokuhin Kogyo Gakkai-Shi 1971, 18, 277-283. [CrossRef]

91. Sun, Y.; Hayakawa, S. Antioxidant effects of Maillard reaction products obtained from ovalbumin and different D-aldohexoses. Biosci. Biotechnol. Biochem. 2006, 70, 598-605. [CrossRef] [PubMed]

92. Superti, F.; Ammendolia, M. Ovotransferrin. In Bioactive Egg Compounds; Huopalahti, R., Lopez-Fandino, R., Anton, M., Eds.; Springer-Verlag: Heidelbert, Germany; Berlin, Germany, 2007; pp. 43-50.

93. Mine, Y.; Kovacs-Nolan, J. Biologically Active Hen Egg Components in Human Health and Disease. J. Poult. Sci. 2004, 41, 1-29. [CrossRef]

94. Fritz, J.; Ikegami, M. Lysozyme ameliorates oxidant-induced lung injury. Am. J. Respir. Crit. Care Med. 2009, 179, A4005.

95. Fossum, K.; Whitaker, J.R. Ficin and papain inhibitor from chicken egg white. Arch. Biochem. Biophys. 1968, 125, 367-375. [CrossRef]

96. Wesierska, E.; Saleh, Y.; Trziszka, T.; Kopec, W.; Siewinski, M.; Korzekwa, K. Antimicrobial activity of chicken egg white cystatin. World J. Microbiol. Biotechnol. 2005, 21, 59-64. [CrossRef]

97. Nicklin, M.; Barrett, A. Inhibition of cysteine proteinases and dipeptidyl peptidase I by egg-white cystatin. Biochem. J. 1984, 223, 245-253. [CrossRef] [PubMed]

98. Vray, B.; Hartmann, S.; Hoebeke, J. Immunomodulatory properties of cystatins. Cell. Mol. Life Sci. 2002, 59, 1503-1512. [CrossRef] [PubMed]

99. Abbas, K.; Breton, J.; Planson, A.G.; Bouton, C.; Bignon, J.; Seguin, C.; Riquier, S.; Toledano, M.B.; Drapier, J.C. Nitric oxide activates an Nrf2/sulfiredoxin antioxidant pathway in macrophages. Free Radic. Biol. Med. 2011, 51, 107-114. [CrossRef] [PubMed]

100. Frenkel, K.; Chrzan, K.; Ryan, C.A.; Wiesner, R.; Troll, W. Chymotrypsin-specific protease inhibitors decrease $\mathrm{H}_{2} \mathrm{O}_{2}$ formation by activated human polymorphonuclear leukocytes. Carcinogenesis 1987, 8, 1207-1212. [CrossRef] [PubMed] 
101. Joubert, F.J.; Cook, W.H. Preparation and characterization of phosvitin from hen egg yolk. Can. J. Biochem. Physiol. 2011, 36, 399-408. [CrossRef]

102. Ishikawa, S.I.; Yano, Y.; Arihara, K.; Itoh, M. Egg yolk phosvitin inhibits hydroxyl radical formation from the fenton reaction. Biosci. Biotechnol. Biochem. 2004, 68, 1324-1331. [CrossRef] [PubMed]

103. Ishikawa, S.; Ohtsuki, S.; Tomita, K.; Arihara, K.; Itoh, M. Protective effect of egg yolk phosvitin against ultraviolet- light-induced lipid peroxidation in the presence of iron ions. Biol. Trace Element Res. 2005, 105, 249-256. [CrossRef]

104. King, M.F.; Boyd, L.C.; Sheldon, B.W. Antioxidant properties of individual phospholipids in a salmon oil model system. J. Am. Oil Chem. Soc. 1992, 69, 545-551. [CrossRef]

105. Saito, H.; Ishihara, K. Antioxidant activity and active sites of phospholipids as antioxidants. J. Am. Oil Chem. Soc. 1997, 74, 1531-1536. [CrossRef]

106. Rao, A.V.; Rao, L.G. Carotenoids and human health. Nutr. Pharmacol. 2007, 55, 207-216. [CrossRef] [PubMed]

107. Fiedor, J.; Burda, K. Potential role of carotenoids as antioxidants in human health and disease. Nutrients 2014, 6, 466-488. [CrossRef] [PubMed]

108. Voutilainen, S.; Nurmi, T.; Mursu, J.; Rissanen, T.H. Carotenoids and cardiovascular health. Am. J. Clin. Nutr. 2006, 83, 1265-1271. [PubMed]

109. Handelman, G.J.; Nightingale, Z.D.; Lichtenstein, A.H.; Schaefer, E.J.; Blumberg, J.B. Lutein and zeaxanthin concentrations in plasma after dietary supplementation with egg yolk. Am. J. Clin. Nutr. 1999, 70, 247-251. [PubMed]

110. Chung, H.-Y.; Rasmussen, H.M.; Johnson, E.J. Lutein bioavailability is higher from lutein-enriched eggs than from supplements and spinach in men. J. Nutr. 2004, 134, 1887-1893. [PubMed]

111. Karadas, F.; Grammenidis, E.; Surai, P.F.; Acamovic, T.; Sparks, N.H. Effects of carotenoids from lucerne, marigold and tomato on egg yolk pigmentation and carotenoid composition. Br. Poult. Sci. 2006, 47, 561-566. [CrossRef] [PubMed]

112. Schlatterer, J.; Breithaupt, D.E. Xanthophylls in commercial egg yolks: Quantification and identification by HPLC and LC-(APCI)MS using a $C_{30}$ phase. J. Agric. Food Chem. 2006, 54, 2267-2273. [CrossRef] [PubMed]

113. Breithaupt, D.E. Modern application of xanthophylls in animal feeding-A review. Trends Food Sci. Technol. 2007, 18, 501-506. [CrossRef]

114. Breithaupt, D.R. Xanthophylls in Poultry Feeding. In Carotenoids; Pfander, H., Ed.; Birkhauser: Basel, Switzerland, 2008; Volume 4, pp. 255-264.

115. Krinsky, N.; Russett, M. Structural and geometrical isomers of carotenoids in human plasma. J. Nutr. 1990, 120, 1654-1662. [PubMed]

116. Landrum, J.T.; Bone, R.A. Lutein, zeaxanthin, and the macular pigment. Arch. Biochem. Biophys. 2001, 385, 28-40. [CrossRef] [PubMed]

117. Krinsky, N.; Landrum, J.; Bone, R. Biologic mechanisms of the protective role of lutein and zeaxanthin in the eye. Annu. Rev. Nutr. 2003, 23, 171-201. [CrossRef] [PubMed]

118. Li, B.; Ahmed, F.; Bernstein, P.S. Studies on the singlet oxygen scavenging mechanism of human macular pigment. Arch. Biochem. Biophys. 2010, 504, 56-60. [PubMed]

119. Böhm, F.; Edge, R.; Truscott, G. Interactions of dietary carotenoids with activated (singlet) oxygen and free radicals: Potential effects for human health. Mol. Nutr. Food Res. 2012, 56, 205-216. [PubMed]

120. Gao, S.; Qin, T.; Liu, Z.; Caceres, M.A.; Ronchi, C.F.; Chen, C.Y.O.; Yeum, K.J.; Taylor, A.; Blumberg, J.B.; $\mathrm{Liu}, \mathrm{Y}$; , et al. Lutein and zeaxanthin supplementation reduces $\mathrm{H}_{2} \mathrm{O}_{2}$-induced oxidative damage in human lens epithelial cells. Mol. Vis. 2011, 17, 3180-3190. [PubMed]

121. Dwyer, J.H.; Navab, M.; Dwyer, K.M.; Hassan, K.; Sun, P.; Shircore, A.; Hama-Levy, S.; Hough, G.; Wang, X.; Drake, T.; et al. Oxygenated Carotenoid Lutein and Progression of Early Atherosclerosis: The Los Angeles Atherosclerosis Study. Circulation 2001, 103, 2922-2927. [CrossRef] [PubMed]

122. Kim, J.E.; Leite, J.O.; DeOgburn, R.; Smyth, J.A.; Clark, R.M.; Fernandez, M.L. A lutein-enriched diet prevents cholesterol accumulation and decreases oxidized LDL and inflammatory cytokines in the aorta of guinea pigs. J. Nutr. 2011, 141, 1458-1463. [CrossRef] [PubMed]

123. Trevithick-Sutton, C.C.; Foote, C.S.; Collins, M.; Trevithick, J.R. The retinal carotenoids zeaxanthin and lutein scavenge superoxide and hydroxyl radicals: A chemiluminescence and ESR study. Mol. Vis. 2006, 12, 1127-1135. [PubMed] 
124. Panasenko, O.M.; Sharov, V.S.; Briviba, K.; Sies, H. Interaction of peroxynitrite with carotenoids in human low density lipoproteins. Arch. Biochem. Biophys. 2000, 373, 302-305. [CrossRef] [PubMed]

125. Traber, M.G.; Atkinson, J. Vitamin E, antioxidant and nothing more. Free Radic. Biol. Med. 2007, 43, 4-15. [CrossRef] [PubMed]

126. Burton, G.W.; Traber, M.G. Vitamin E: Antioxidant activity, biokinetics, and bioavailability. Annu. Rev. Nutr. 1990, 10, 357-382. [CrossRef] [PubMed]

127. Esterbauer, H.; Puhl, H.; Dieber-Rotheneder, M.; Waeg, G.; Rabl, H. Effect of antioxidants on oxidative modification of LDL. Ann. Med. 1991, 23, 573-581. [CrossRef] [PubMed]

128. Rimm, E.B.; Stampfer, M.J.; Ascherio, A.; Giovannucci, E.; Colditz, G.A.; Willett, W.C. Vitamin E consumption and the risk of coronary heart disease in men. N. Engl. J. Med. 1993, 328, 1450-1456. [CrossRef] [PubMed]

129. Stampfer, M.J.; Hennekens, C.H.; Manson, J.E.; Colditz, G.A.; Rosner, B.; Willett, W.C. Vitamin E consumption and the risk of coronary disease in women. N. Engl. J. Med. 1993, 328, 1444-1449. [CrossRef]

130. Surai, P.F.; MacPherson, A.; Speake, B.K.; Sparks, N.H.C. Designer egg evaluation in a controlled trial. Eur. J. Clin. Nutr. 2000, 54, 298-305. [CrossRef] [PubMed]

131. Tapiero, H.; Townsend, D.; Tew, K. The antioxidant role of selenium and seleno-compounds. Biomed. Pharmacother. 2003, 57, 134-144. [CrossRef]

132. Smyth, P.P.A. Role of iodine in antioxidant defence in thyroid and breast disease. BioFactors 2003, 19, 121-130. [CrossRef] [PubMed]

133. Chen, C.; Chi, Y.-J.; Zhao, M.-Y.; Lv, L. Purification and identification of antioxidant peptides from egg white protein hydrolysate. Amino Acids 2012, 43, 457-466. [CrossRef] [PubMed]

134. Remanan, M.K.; Wu, J. Antioxidant activity in cooked and simulated digested eggs. Food Funct. 2014, 5, 1464-1474. [PubMed]

135. Chen, C.; Chi, Y.; Xu, W. Comparisons on the functional properties and antioxidant activity of spray-dried and freeze-dried egg white protein hydrolysate. Food Bioprocess Technol. 2012, 5, 2342-2352. [CrossRef]

136. Lin, S.; Jin, Y.; Liu, M.; Yang, Y.; Zhang, M.; Guo, Y. Research on the preparation of antioxidant peptides derived from egg white with assisting of high-intensity pulsed electric field. Food Chem. 2013, 139, 300-306. [CrossRef] [PubMed]

137. Liu, J.; Jin, Y.; Lin, S.; Jones, G.S.; Chen, F. Purification and identification of novel antioxidant peptides from egg white protein and their antioxidant activities. Food Chem. 2015, 175, 258-266. [CrossRef] [PubMed]

138. Nimalaratne, C.; Bandara, N.; Wu, J. Purification and characterization of antioxidant peptides from enzymatically hydrolyzed chicken egg white. Food Chem. 2015, 188, 467-472. [CrossRef] [PubMed]

139. Graszkiewicz, A.; Zelazko, M. Antioxidative capacity of hydrolysates of hen egg proteins. Pol. J. Food Nutr. Sci. 2007, 57, 195-199.

140. Graszkiewicz, A.; Zelazko, M.; Trziszka, T. Application of pancreatic enzymes in hydrolysis of egg-white proteins. Pol. J. Food Nutr. Sci. 2010, 60, 57-61.

141. Manso, M.; Miguel, M.; Even, J.; Hernandez, R.; Aleixandre, A.; Lopezfandino, R. Effect of the long-term intake of an egg white hydrolysate on the oxidative status and blood lipid profile of spontaneously hypertensive rats. Food Chem. 2008, 109, 361-367. [CrossRef]

142. Park, P.-J.; Jung, W.-K.; Nam, K.-S.; Shahidi, F.; Kim, S.-K. Purification and characterization of antioxidative peptides from protein hydrolysate of lecithin-free egg yolk. J. Am. Oil Chem. Soc. 2001, 78, 651-656. [CrossRef]

143. Sakanaka, S.; Tachibana, Y. Active oxygen scavenging activity of egg-yolk protein hydrolysates and their effects on lipid oxidation in beef and tuna homogenates. Food Chem. 2006, 95, 243-249. [CrossRef]

144. Xu, M.; Shangguan, X.; Wang, W.; Chen, J. Antioxidative activity of hen egg ovalbumin hydrolysates. Asia Pac. J. Clin. Nutr. 2007, 16, 178-182. [PubMed]

145. Shen, S.; Chahal, B.; Majumder, K. Identification of novel antioxidative peptides derived from a thermolytic hydrolysate of ovotransferrin by LC-MS/MS. J. Agric. Food Chem. 2010, 58, 7664-7672. [CrossRef] [PubMed]

146. Huang, W.; Shen, S.; Nimalaratne, C.; Li, S.; Majumder, K.; Wu, J. Effects of addition of egg ovotransferrin-derived peptides on the oxygen radical absorbance capacity of different teas. Food Chem. 2012, 135, 1600-1607. [CrossRef] [PubMed] 
147. Galisteo, J.; Herraiz, T. Endogenous and Dietary Indoles: A Class of Antioxidants and Radical Scavengers in the ABTS Assay. Free Radic. Res. 2004, 38, 323-331.

148. Christen, S.; Peterhans, E.; Stocker, R. Antioxidant activities of some tryptophan metabolites: Possible implication for inflammatory diseases. Proc. Natl. Acad. Sci. USA 1990, 87, 2506-2510. [CrossRef] [PubMed]

149. You, J.; Luo, Y.; Wu, J. Conjugation of Ovotransferrin with Catechin Shows Improved Antioxidant Activity. J. Agric. Food Chem. 2014, 62, 2581-2587. [CrossRef] [PubMed]

150. Rao, S.; Sun, J.; Liu, Y.; Zeng, H.; Su, Y.; Yang, Y. ACE inhibitory peptides and antioxidant peptides derived from in vitro digestion hydrolysate of hen egg white lysozyme. Food Chem. 2012, 135, 1245-1252. [CrossRef] [PubMed]

151. You, S.-J.; Udenigwe, C.C.; Aluko, R.E.; Wu, J. Multifunctional peptides from egg white lysozyme. Food Res. Int. 2010, 43, 848-855. [CrossRef]

152. Memarpoor-Yazdi, M. A novel antioxidant and antimicrobial peptide from hen egg white lysozyme hydrolysates. J. Funct. Foods 2012, 4, 278-286. [CrossRef]

153. Omana, D.A.; Wang, J.; Wu, J. Ovomucin-A glycoprotein with promising potential. Trends Food Sci. Technol. 2010, 21, 455-463. [CrossRef]

154. Liu, J.; Chen, Z.; He, J.; Zhang, Y.; Zhang, T.; Jiang, Y. Anti-oxidative and anti-apoptosis effects of egg white peptide, Trp-Asn-Trp-Ala-Asp, against $\mathrm{H}_{2} \mathrm{O}_{2}$-induced oxidative stress in human embryonic kidney 293 cells. Food Funct. 2014, 5, 3179-3188. [CrossRef] [PubMed]

155. Katayama, S.; Xu, X.; Fan, M.Z.; Mine, Y. Antioxidative stress activity of oligophosphopeptides derived from hen egg yolk phosvitin in Caco-2 cells. J. Agric. Food Chem. 2006, 54, 773-778. [PubMed]

156. Xu, X.; Katayama, S.; Mine, Y. Antioxidant activity of tryptic digests of hen egg yolk phosvitin. J. Sci. Food Agric. 2007, 87, 2604-2608. [CrossRef] [PubMed]

157. Katayama, S.; Mine, Y. Antioxidative activity of amino acids on tissue oxidative stress in human intestinal epithelial cell model. J. Agric. Food Chem. 2007, 55, 8458-8464. [CrossRef] [PubMed]

158. Surai, P.F.; Simons, P.C.M.; Dvorska, J.E.; Aradas, F.; Sparks, N.H.C. Antioxidant-enriched eggs: Opportunities and limitations. In The Amazing Egg: Nature's Perfect Functional Food for Health Promotion; Sim, J.S., Sunwoo, H.H., Eds.; University of Alberta: Edmonton, AB, Canada, 2006; pp. 68-93.

159. Fraeye, I.; Bruneel, C.; Lemahieu, C.; Buyse, J.; Muylaert, K.; Foubert, I. Dietary enrichment of eggs with omega-3 fatty acids: A review. Food Res. Int. 2012, 48, 961-969. [CrossRef]

160. Leeson, S. Lutein-Enriched eggs: Transfer of lutein into eggs and health benefits. In The Amazing Egg: Nature's Perfect Functional Food for Health Promotion; Sim, J.S., Sunwoo, H.H., Eds.; Department of Agricultural, Food and Nutritional Science, University of Alberta: Edmonton, AB, Canada, 2006; pp. 171-179.

161. Serpeloni, J.M.; Grotto, D.; Mercadante, A.Z.; de Lourdes Pires Bianchi, M.; Antunes, L.M.G. Lutein improves antioxidant defense in vivo and protects against DNA damage and chromosome instability induced by cisplatin. Arch. Toxicol. 2010, 84, 811-822. [CrossRef] [PubMed]

162. Roberts, R.L.; Green, J.; Lewis, B. Lutein and zeaxanthin in eye and skin health. Clin. Dermatol. 2009, 27, 195-201. [CrossRef] [PubMed]

163. Wertz, K.; Siler, U.; Goralczyk, R. Lycopene: Modes of action to promote prostate health. Arch. Biochem. Biophys. 2004, 430, 127-134. [CrossRef] [PubMed]

164. Olson, J.B.; Ward, N.E.; Koutsos, E.A. Lycopene Incorporation into Egg Yolk and Effects on Laying Hen Immune Function. Poult. Sci. 2008, 87, 2573-2580. [CrossRef] [PubMed]

165. Akdemir, F.; Orhan, C.; Sahin, N.; Sahin, K.; Hayirli, A. Tomato powder in laying hen diets: Effects on concentrations of yolk carotenoids and lipid peroxidation. Br. Poult. Sci. 2012, 53, 675-680. [CrossRef]

166. Péter, S.; Moser, U. The challenge of setting appropriate intake recommendations for vitamin E: Considerations on status and functionality to define nutrient requirements. Int. J. Vitam. Nutr. Res. 2013, 83, 129-136. [CrossRef] [PubMed]

167. Sanders, T.A.B.; Hinds, A. The influence of a fish oil high in docosahexaenoic acid on plasma lipoprotein and vitamin E concentrations and haemostatic function in healthy male volunteers. Br. J. Nutr. 2007, 68, 163-173. [CrossRef]

168. Valk, E.; Hornstra, G. Relationship between vitamin E requirement and polyunsaturated fatty acid intake in man: A review. Int. J. Vitam. Nutr. Res. 2000, 70, 31-42. [CrossRef] [PubMed] 
169. Honein, M.A. Impact of folic acid fortification of the US food supply on the occurrence of neural tube defects. JAMA 2001, 285, 2981-2986. [CrossRef] [PubMed]

170. House, J.D.; Braun, K.; Ballance, D.; O'Connor, C.; Guenter, W. The enrichment of eggs with folic acid through supplementation of the laying hen diet. Poult. Sci. 2002, 81, 1332-1337. [CrossRef] [PubMed]

171. House, J.D.; O'Connor, C.; Guenter, W. Plasma homocysteine and glycine are sensitive indices of folate status in a rodent model of folate depletion and repletion. J. Agric. Food Chem. 2003, 51, 4461-4467. [CrossRef] [PubMed]

172. Seyoum, E.; Selhub, J. Properties of Food Folates Determined by Stability and Susceptibility to Intestinal Pteroylpolyglutamate Hydrolase Action. J. Nutr. 1998, 128, 1956-1960. [PubMed]

173. Rezk, B.M.; Haenen, G.R.M.; van der Vijgh, W.J.; Bast, A. Tetrahydrofolate and 5-methyltetrahydrofolate are folates with high antioxidant activity. Identification of the antioxidant pharmacophore. FEBS Lett. 2003, 555, 601-605. [CrossRef]

174. Antoniades, C.; Shirodaria, C.; Warrick, N.; Cai, S.; de Bono, J.; Lee, J.; Leeson, P.; Neubauer, S.; Ratnatunga, C.; Pillai, R.; et al. 5-methyltetrahydrofolate rapidly improves endothelial function and decreases superoxide production in human vessels: Effects on vascular tetrahydrobiopterin availability and endothelial nitric oxide synthase coupling. Circulation 2006, 114, 1193-1201. [CrossRef] [PubMed]

175. Verhaar, M.C.; Wever, R.M.F.; Kastelein, J.J.P.; van Dam, T.; Koomans, H.A.; Rabelink, T.J. 5-Methyltetrahydrofolate, the Active Form of Folic Acid, Restores Endothelial Function in Familial Hypercholesterolemia. Circulation 1998, 97, 237-241. [CrossRef] [PubMed]

176. Dobrzanski, Z.; Gorecka, H.; Strzelbicka, G.; Szczypel, J.; Trziszka, T. Study on enrichment of hen eggs with selenium and iodine. Electron. J. Pol. Agric. Univ. Ser. Anim. Husb. 2001, 4. Available online: http:/ / www.ejpau.media.pl/volume4/issue2/animal/art-01.html (accessed on 25 September 2014).

177. Nicoli, M.; Anese, M.; Parpinel, M. Influence of processing on the antioxidant properties of fruit and vegetables. Trends Food Sci. Technol. 1999, 10, 94-100. [CrossRef]

178. Kalt, W. Effects of production and processing factors on major fruit and vegetable antioxidants. J. Food Sci. 2005, 70, R11-R19. [CrossRef]

179. Shi, J.; le Maguer, M. Lycopene in tomatoes: Chemical and physical properties affected by food processing. Crit. Rev. Food Sci. Nutr. 2000, 40, 1-42. [CrossRef] [PubMed]

180. Dewanto, V.; Wu, X.; Adom, K.K.; Liu, R.H. Thermal processing enhances the nutritional value of tomatoes by increasing total antioxidant activity. J. Agric. Food Chem. 2002, 50, 3010-3014. [CrossRef] [PubMed]

181. Dewanto, V.; Wu, X.; Liu, R.H. Processed sweet corn has higher antioxidant activity. J. Agric. Food Chem. 2002, 50, 4959-4964. [CrossRef] [PubMed]

182. Adefegha, S.; Oboh, G. Cooking enhances the antioxidant properties of some tropical green leafy vegetables. Afr. J. Biotechnol. 2013, 10, 632-639.

183. Turkmen, N.; Sari, F.; Velioglu, Y.S. The effect of cooking methods on total phenolics and antioxidant activity of selected green vegetables. Food Chem. 2005, 93, 713-718. [CrossRef]

184. Ravichandran, K.; Saw, N.M.M.T.; Mohdaly, A.A.A.; Gabr, A.M.M.; Kastell, A.; Riedel, H.; Cai, Z.; Knorr, D.; Smetanska, I. Impact of processing of red beet on betalain content and antioxidant activity. Food Res. Int. 2013, 50, 670-675. [CrossRef]

185. Ismail, A.; Marjan, Z.M.; Foong, C.W. Total antioxidant activity and phenolic content in selected vegetables. Food Chem. 2004, 87, 581-586. [CrossRef]

186. Natella, F.; Belelli, F.; Ramberti, A.; Scaccini, C. Microwave and traditional cooking methods: Effect of cooking on antioxidant. J. Food Biochem. 2010, 34, 796-810.

187. Zhang, D.; Hamauzu, Y. Phenolics, ascorbic acid, carotenoids and antioxidant activity of broccoli and their changes during conventional and microwave cooking. Food Chem. 2004, 88, 503-509. [CrossRef]

188. Jing, H.; Yap, M.; Wong, P.Y.Y.; Kitts, D.D. Comparison of physicochemical and antioxidant properties of egg-white proteins and fructose and inulin maillard reaction products. Food Bioprocess Technol. 2009, 4, 1489-1496. [CrossRef]

189. Albright, K.; Gordon, D.; Cotterill, O. Release of iron from phosvitin by heat and food additives. J. Food Sci. 1984, 49, 78-81. [CrossRef]

190. Schieber, A.; Carle, R. Occurrence of carotenoid cis-isomers in food: Technological, analytical, and nutritional implications. Pigment. Food 2005, 16, 416-422. [CrossRef] 
191. Wenzel, M.; Seuss-Baum, I.; Schlich, E. Influence of pasteurization, spray- and freeze-drying, and storage on the carotenoid content in egg yolk. J. Agric. Food Chem. 2010, 58, 1726-1731. [CrossRef] [PubMed]

192. Barbosa, V.C.; Gaspar, A.; Calixto, L.F.L.; Agostinho, T.S.P. Stability of the pigmentation of egg yolks enriched with omega-3 and carophyll stored at room temperature and under refrigeration. Rev. Bras. Zootec. 2011, 40, 1540-1544.

193. Galobart, J.; Barroeta, A. $\alpha$-Tocopherol transfer efficiency and lipid oxidation in fresh and spray-dried eggs enriched with omega-3-polyunsaturated fatty acids. Poult. Sci. 2001, 80, 1496-1505. [CrossRef] [PubMed]

194. Caboni, M.; Boselli, E.; Messia, M. Effect of processing and storage on the chemical quality markers of spray-dried whole egg. Food Chem. 2005, 92, 293-303. [CrossRef]

195. Stefanović, A.B.; Jovanović, J.R.; Grbavčić, S.Ž.; Šekuljica, N.Ž.; Manojlović, V.B.; Bugarski, B.M.; Knežević-Jugović, Z.D. Impact of ultrasound on egg white proteins as a pretreatment for functional hydrolysates production. Eur. Food Res. Technol. 2014, 239, 979-993. [CrossRef]

196. Van der Plancken, I.; Van Loey, A.; Hendrickx, M.E. Combined effect of high pressure and temperature on selected properties of egg white proteins. Innov. Food Sci. Emerg. Technol. 2005, 6, 11-20. [CrossRef]

197. Mateo Anson, N.; Havenaar, R.; Bast, A.; Haenen, G.R.M.M. Antioxidant and anti-inflammatory capacity of bioaccessible compounds from wheat fractions after gastrointestinal digestion. J. Cereal Sci. 2010, 51, 110-114. [CrossRef]

198. Chiang, C.-J.; Kadouh, H.; Zhou, K. Phenolic compounds and antioxidant properties of gooseberry as affected by in vitro digestion. LWT Food Sci. Technol. 2013, 51, 417-422. [CrossRef]

199. Tagliazucchi, D.; Verzelloni, E.; Bertolini, D.; Conte, A. In vitro bio-accessibility and antioxidant activity of grape polyphenols. Food Chem. 2010, 120, 599-606. [CrossRef]

200. Rodríguez-Roque, M.J.; Rojas-Graü, M.A.; Elez-Martínez, P.; Martín-Belloso, O. Soymilk phenolic compounds, isoflavones and antioxidant activity as affected by in vitro gastrointestinal digestion. Food Chem. 2013, 136, 206-212. [CrossRef] [PubMed]

201. Jensen, I.-J.; Abrahamsen, H.; Maehre, H.K.; Elvevoll, E.O. Changes in antioxidative capacity of saithe (Pollachius virens) and shrimp (Pandalus borealis) during in vitro digestion. J. Agric. Food Chem. 2009, 57, 10928-10932. [CrossRef] [PubMed]

202. You, L.; Zhao, M.; Regenstein, J.M.; Ren, J. Changes in the antioxidant activity of loach (Misgurnus anguillicaudatus) protein hydrolysates during a simulated gastrointestinal digestion. Food Chem. 2010, 120, 810-816. [CrossRef]

203. Bouayed, J.; Hoffmann, L.; Bohn, T. Total phenolics, flavonoids, anthocyanins and antioxidant activity following simulated gastro-intestinal digestion and dialysis of apple varieties: Bioaccessibility and potential uptake. Food Chem. 2011, 128, 14-21. [CrossRef] [PubMed]

204. Faller, A.L.K.; Fialho, E.; Liu, R.H. Cellular antioxidant activity of feijoada whole meal coupled with an in vitro digestion. J. Agric. Food Chem. 2012, 60, 4826-4832. [PubMed]

205. Nimalaratne, C.; Savard, P.; Gauthier, S.F.; Schieber, A.; Wu, J. Bioaccessibility and digestive stability of carotenoids in cooked eggs studied using a dynamic in vitro gastrointestinal model. J. Agric. Food Chem. 2015, 63, 2956-2962. [CrossRef] [PubMed]

(C) 2015 by the authors; licensee MDPI, Basel, Switzerland. This article is an open access article distributed under the terms and conditions of the Creative Commons by Attribution (CC-BY) license (http://creativecommons.org/licenses/by/4.0/). 